\title{
The Earnings/Price Risk Factor in Capital Asset Pricing Models
}

Rafael Falcão Noda

Ph.D student, Department of Administration, School of Economics, Business and Accounting, University of São Paulo.

E-mail: rafaelnoda@usp.br

\section{Roy Martelanc}

Ph.D professor, Department of Administration, School of Economics, Business and Accounting, Úniversity of São Paulo.

E-mail: rmartela@usp.br

Eduardo Kazuo Kayo

Ph.D professor, Department of Administration, School of Economics, Business and Accounting, University of São Paulo.

E-mail: kayo@usp.br

Received on 11.01.2013-Desk acceptance on 11.12.2013-2 $2^{\text {th }}$ version approved on 09.25.2014

\begin{abstract}
This article integrates the ideas from two major lines of research on cost of equity and asset pricing: multi-factor models and ex ante accounting models. The earnings/price ratio is used as a proxy for the ex ante cost of equity, in order to explain realized returns of Brazilian companies within the period from 1995 to 2013. The initial finding was that stocks with high (low) earnings/price ratios have higher (lower) risk-adjusted realized returns, already controlled by the capital asset pricing model's beta. The results show that selecting stocks based on high earnings/price ratios has led to significantly higher risk-adjusted returns in the Brazilian market, with average abnormal returns close to $1.3 \%$ per month. We design asset pricing models including an earnings/price risk factor, i.e. high earnings minus low earnings, based on the Fama and French three-factor model. We conclude that such a risk factor is significant to explain returns on portfolios, even when controlled by size and market/book ratios. Models including the high earnings minus low earnings risk factor were better to explain stock returns in Brazil when compared to the capital asset pricing model and to the Fama and French three-factor model, having the lowest number of significant intercepts. These findings may be due to the impact of historically high inflation rates, which reduce the information content of book values, thus making the models based on earnings/price ratios better than those based on market/book ratios. Such results are different from those obtained in more developed markets and the superiority of the earnings/price ratio for asset pricing may also exist in other emerging markets.
\end{abstract}

Keywords: Cost of equity, Asset pricing, Multi-factor models. 


\section{INTRODUCTION}

Cost of equity estimation is a widely studied topic in finance and, at the same time, it offers plenty of room for new developments. In fact, according to Cochrane (2010), theories on the formation of discount rates are controversial and are still in their infancy.

Recent studies seek to design more accurate asset pricing models by adding risk factors other than market risk from the capital asset pricing model (CAPM), such as those developed and applied by Fama and French (1992), Fama and French (1993), Carhart (1997), and Fama and French (2012).

Another line of research seeks to estimate the ex ante or implied cost of equity, mainly based on the relation between a company's market value of equity and its expected future cash flow, which is measured according to earnings and/or dividends estimates.

Studies using this type of methodology were conducted by Claus and Thomas (2001), Fama and French (2002), Ohlson and Juettner-Nauroth (2005), and Easton (2004). Such models are usually based on current prices and expected earnings. Specifically, in the more advanced models of Ohlson and Juettner-Nauroth (2005) and Easton (2004), the ex ante cost of equity is equal to the earnings/price $(\mathrm{E} / \mathrm{P})$ ratio when there are no abnormal earnings. Thus, the $\mathrm{E} / \mathrm{P}$ ratio may be a proxy for the implied cost of equity that, in turn, may be an explanatory factor for realized returns, as identified by Basu (1977).

Using elements of both approaches, the objectives of this study are, having a Brazilian sample as a basis, (i) checking if the realized returns on portfolios formed having the stocks' E/P ratio as a basis are significantly different from those predicted by the CAPM, using Jensen's alpha methodology; and (ii) assessing asset pricing models based on the CAPM and on the Fama and French three-factor model added with a risk factor related to the $\mathrm{E} / \mathrm{P}$ ratio, i.e. high earnings minus low earnings (HEM$\mathrm{LE})$, as an explanatory variable for realized returns.

The selection of a Brazilian sample may have two advantages when analyzing the explanatory power of the $\mathrm{E} / \mathrm{P}$ risk factor. First, Brazil has a much higher inflation rate when compared to more developed markets, such as the U.S. The consequence is that the explanatory power of Fama and French's high minus low (HML) risk factor may be lower, since book values may be severely influenced by the assets' age, making market/book (M/B) ratios less meaningful. Therefore, the $\mathrm{E} / \mathrm{P}$ ratio may be a better or, at least, supplementary measure to identify "cheap" and "expensive" assets. Second, the Brazilian market may be regarded as less liquid and efficient, it has more apparent asset pricing imperfections.

The main hypotheses are that (i) the asset portfolios with high (low) E/P ratios tend to have higher (lower) returns than those predicted by the CAPM; and (ii) the $\mathrm{E} / \mathrm{P}$ risk factor is significant to explain the portfolios' realized returns.

This study extends other studies conducted in the Brazilian market, both by adding the HEMLE risk factor and expanding the sample and the analytical period, as suggested by Costa Jr. and Neves (2000), in addition to testing Jensen's alphas of portfolios formed having earnings/stock price indexes as a basis.

Both hypotheses are confirmed, concluding that stocks with high (low) E/P ratios, i.e. with potentially high (low) implied cost of equity, have higher (lower) returns, which are not explained by the CAPM, as well as that the HEMLE risk factor is significant to explain returns on portfolios of Brazilian stocks, even when controlled by Fama and French's small minus big (SMB) and HML risk factors. The models including the HEMLE risk factor also had higher explanatory power and they were capable to eliminate most of the intercepts, i.e. unexplained abnormal returns.

Corroborating the idea that $\mathrm{M} / \mathrm{B}$ ratios are less meaningful in Brazil to identify "cheap" and "expensive" stocks, due to higher inflation, the results also show that portfolios ranked by $\mathrm{M} / \mathrm{B}$ ratios do not show abnormal returns.

This study is structured as follows: after this brief introduction, we introduce the theoretical framework in section 2 , section 3 consists in the methodology and sample description, section 4 contains the results and their analysis, and, finally, the conclusions are drawn in section 5 .

\section{THEORETICAL FRAMEWORK}

\subsection{Capital asset pricing model}

Inspired by the portfolio theory developed by Markowitz (1952), which is based on optimizing the relation between risk and return, Sharpe (1964) and Lintner (1965) developed the CAPM, suggesting that, under conditions of market equilibrium, the expected return on a given asset above the risk-free rate should be proportional to its non-diversifiable risk, or market risk, measured by $\beta$ :

$$
E\left[R_{t}\right]=R F_{t}+\beta\left(E\left[R M_{t}\right]-R F_{t}\right)
$$

$$
\beta=\frac{\operatorname{Cov}\left(R_{t}, R M_{t}\right)}{\operatorname{Var}\left(R M_{t}\right)}
$$

Where $R_{t}$ is the return on a given asset at the period $t$, $\mathrm{RF}_{\mathrm{t}}$ is the risk-free rate or the return on an asset with $\beta=$ $0, \beta$ is the measure of non-diversifiable risk of a certain asset, and $\mathrm{RM}_{\mathrm{t}}$ is the return on the market portfolio. $\mathrm{E}[$.] is the expectation operator.

The CAPM predicts that the market portfolio consists of all available assets, each having a weight propor- 
tional to its market value, and the market risk factor, i.e. $\mathrm{RM}-\mathrm{RF}$, is the only factor capable to explain returns on asset.

\subsection{The Fama and French three-factor model}

Fama and French (1993) tested several explanatory models for realized returns in the U.S., including equities (stocks) and fixed income (bonds). For stocks, they use the following risk factors: (i) RM-RF, representing the market risk factor; (ii) SMB, representing the size risk factor; and (iii) HML, representing a risk factor related to the book/market $(\mathrm{B} / \mathrm{M})$ ratio.

The authors use the returns on 25 portfolios in excess of the risk-free rate, $R_{t}-R_{t}$, as dependent variables. Such portfolios are formed having quintiles of size as a basis, measured by market capitalization, and $\mathrm{B} / \mathrm{M}$ ratios. Formally, the time-series regressions used by the authors are:

$$
R_{t}-R F_{t}=a+b\left(R M_{t}-R F_{t}\right)+s\left(S M B_{t}\right)+h\left(H M L_{t}\right)+e_{t}
$$

Where $a, b, s, h$ are the regression coefficients and RM-RF, SMB, and HML are explanatory risk factors, as described above.

Fama and French (1993) conclude that the factors RM-RF, SMB, and HML are significant to explain portfolio returns, and they add explanatory power to the asset pricing models, measured by significantly higher $\mathrm{R}^{2}$ when compared to models with fewer factors. The models' $\mathrm{R}^{2}$ exceed $90 \%$ for most portfolios.

\subsection{The relevance of the earnings/price risk} factor to explain returns and ex ante models

Basu (1977) conducted a seminal study relating price/earnings (P/E) ratios to realized returns on stock. The author used a sample of 500 companies traded on the New York Stock Exchange (NYSE) within the period from 1956 to 1969, grouping them into 5 portfolios according to their P/E ratios. He performed a regression whose dependent variable was the return on a given portfolio and the independent variable was the market risk factor:

$$
R(t)-R F(t)=\alpha+\beta[R M(t)-R F(t)]
$$

Where the intercept, $\alpha$, is Jensen's alpha (Jensen, 1968).

Basu (1977) found positive and significant alphas for the 2 portfolios consisting of stocks with low P/E ratios and negative alphas for the 2 portfolios consisting of sto- cks with high $\mathrm{P} / \mathrm{E}$ ratios, concluding that the $\mathrm{P} / \mathrm{E}$ ratio may have been a relevant factor to explain returns and that this fact may be an indication of market inefficiencies.

The main models for calculating the ex ante cost of equity also use the stocks' price and earnings to estimate expected returns. Gebhardt, Lee and Swaminathan (2001), for instance, use a model of discounted abnormal earnings, where the cost of equity, or expected return, is a function of the market value, the expected earnings, and book value of equity:

$$
V_{t}=B_{t}+\sum_{i=1}^{\infty} \frac{E_{t+i}-r B_{t+i-1}}{(1+r)^{i}}
$$

Where $V_{t}$ is the market value at the period $t, B_{t}$ is the book value of equity at the period $t, E_{t}$ is the net income at the period $t$, and $r$ is the cost of equity.

Claus and Thomas (2001), aiming to estimate the ex ante market risk premium, use a model similar to that developed by Gebhardt et al. (2001), adopting the concept of abnormal earnings as those that exceed the book value of equity multiplied by the cost of equity. Both models are based on the clean surplus accounting methodology (Feltham \& Ohlson, 1995).

Ohlson and Juettner-Nauroth (2005) developed a model relating price, earnings, abnormal earnings, and cost of equity:

$$
P_{0}=\frac{e p s_{1}}{k}+\sum_{i=1}^{\infty} R^{-t} r^{-1}\left(e p s_{t+1}+k \cdot d p s_{t}-K \cdot e p s_{t}\right)
$$

Where $\mathrm{P}_{t}$ is the stock price at the period $t, k$ is the cost of equity, $\mathrm{K}=1+\mathrm{k}$, eps $\mathrm{s}_{\mathrm{t}}$ is the earnings per share at the period $\mathrm{t}$, and $\mathrm{dps}$, is the dividend per share at the period $t$.

Easton (2004) developed a model based on Ohlson and Juettner-Nauroth (2000), which is the precursor of Ohlson and Juettner-Nauroth (2005):

$$
P_{0}=\frac{e p s_{1}}{k}+k^{-1} \sum_{t=1}^{\infty}(1+k)^{-1} a g r_{t}
$$

Where $P_{t}$ is the price per share at the period t, eps is the earnings per share at the period $t, k$ is the cost of equity, and agr is the abnormal growth in account earnings, defined as follows:

$$
e p s_{t+1}+k\left(d p s_{t}\right)-(1+k) e p s_{t}
$$

Where dps is the dividend per share at the period $t$.

When the companies do not have abnormal earnings, or agr $=0$, Easton's model is reduced to:

$$
P_{0}=\frac{e p s_{1}}{k}
$$

In this scenario, the implied cost of equity is equivalent to the earnings yield, or E/P: 


$$
k=\frac{e p s_{1}}{P_{0}}
$$

Therefore, in the absence of abnormal earnings, the $\mathrm{E} / \mathrm{P}$ ratio is equivalent to the expected returns.

The ex ante models are used as the basis for many subsequent studies, such as Attig, Guedhami and Mishra (2008) and Hail and Leuz (2009).

\subsection{The relation between earnings yields and $\mathrm{B} / \mathrm{M}$ ratios}

Some studies test the relation between earnings and other asset pricing risk factors. Fama and French (1995), based on the Fama and French three-factor model, argue that (i) two variables, market equity and $\mathrm{B} / \mathrm{M}$ ratios, capture much of the cross-section of average stock returns; and (ii) such variables are able to predict the evolution of the profitability of listed companies. The authors conclude that companies with high $\mathrm{B} / \mathrm{M}$ ratios tend to be distressed and have low future profitability. Fama and French (1996), in a related study, apply the Fama and French three-factor model to portfolios separately sorted by deciles of $\mathrm{B} / \mathrm{M}, \mathrm{E} / \mathrm{P}$, cash flow/price $(\mathrm{C} / \mathrm{P})$, and 5-year sales growth (SG). They show that, while there is a strong positive relation between average return and $\mathrm{B} / \mathrm{M}, \mathrm{E} / \mathrm{P}, \mathrm{C} / \mathrm{P}$, and SG, the three-factor model is capable to explain such "anomalies", with regression intercepts that are consistently small.

\subsection{Brazilian studies}

Costa Jr. and Neves (2000) tested the influence of fundamentalist variables in the returns on portfolios consisting of stocks traded on the Brazilian market from March 1987 to February 1996, using the seemingly unrelated regression (SUR) estimator. The authors found significant and negative coefficients for the variables
$\mathrm{P} / \mathrm{E}$ and the natural logarithm of the market value (MV) of firms and positive and significant coefficients for the variable book value per share/price per share (VPA/P). They also conclude that the beta estimated by using the BOVESPA index is the most relevant variable to explain returns. In addition, the authors suggest conducting similar studies at periods of greater economic stability and low inflation.

Málaga and Securato (2004) confirm that the three-factor model is better than the CAPM to explain Brazilian stock returns.

Mussa, Santos and Famá (2007) use a similar methodology, also for a sample of stocks listed on BOVESPA, within the period from 1995 to 2003. They test it by adding the market moment risk factor, as proposed by Carhart (1997), to the three-factor model, concluding the superiority of the proposed model of four factors in the Brazilian market, both regarding the three-factor model and the CAPM.

Mussa, Rogers and Securato (2009) go a step further, in order to test the models' predictive ability. To do this, they carry out a study in two stages, the first similar to that conducted by Mussa et al. (2007) and the second based on the methodology proposed by Fama and MacBeth (1973), which consists of cross-section regressions using risk parameters estimated in the previous period. They conclude that none of the tested models (CAPM, three-factor, and four-factor) were efficient to predict the Brazilian returns on stock, since they found significant intercepts.

Finally, Yoshino and Santos (2009) tested the market, size, $\mathrm{B} / \mathrm{M}, \mathrm{P} / \mathrm{E}$, and dividend yield risk factors, using regressions based on the panel fully modified OLS (FMOLS) estimator, in order to test the validity of the CAPM in Brazil. They concluded that these factors were able to explain returns on stock in Brazil, along with the market factor.

\section{METHODOLOGY}

\subsection{Sample}

The sample consists of all companies listed on the São Paulo Stock Exchange (BOVESPA), within the period from January 1995 to March 2013. We used monthly returns, resulting in 219 periods. In each period, we excluded the stocks that do not have at least one of the following data: stock price, book value of equity, net income, and market value of equity. The average number of stocks used for the period was 187 .

\subsection{Variables}

Similarly to Fama and French (1993), we used time series regressions, where the dependent variables are the excess monthly return on stock portfolios in relation to the risk-free rate, i.e. $\mathrm{R}_{\mathrm{i}, \mathrm{t}}-\mathrm{RF}_{\mathrm{t}}$, and the explanatory variables are a vector of risk factors.

\subsection{Formation of portfolios}

We used as dependent variables the returns on portfolios based on: (i) the market value (MV) of equity, as a firm size measure; (ii) the book value of equity/market value of equity $(\mathrm{B} / \mathrm{M})$ ratio; and (iii) earnings/price $(\mathrm{E} / \mathrm{P})$ ratio.

We used risk factors as explanatory variables, which include the following: market (RM - RF), SMB, HML, and HEMLE. The variables are defined in Table 1. 


\begin{tabular}{l|l}
\hline Variable & Calculation method \\
\hline MV & $\begin{array}{l}\text { Market value of equity at the end of each period, considering the price of each class of stocks multiplied by the respective number of } \\
\text { stocks, as provided by the Economatica database. }\end{array}$ \\
\hline B/M & Book value of equity at the end of each period, divided by the market value of equity, MV, as defined above. \\
\hline E/P & Earnings per share in the last 12 months divided by the stock price, as provided by the Economatica database. \\
\hline RM - RF & $\begin{array}{l}\text { Monthly return on the market portfolio, calculated as the average return on all stocks traded on BOVESPA, weighted by their market } \\
\text { value, minus the SELIC rate at the same period. }\end{array}$ \\
\hline SMB & $\begin{array}{l}\text { Small minus big: monthly return weighted by market value on the portfolio S, minus monthly return weighted by the market value } \\
\text { on portfolio B. }\end{array}$ \\
\hline HML & $\begin{array}{l}\text { High minus low: monthly return weighted by market value on the portfolio H, minus monthly return weighted by the market value } \\
\text { on the portfolio L. }\end{array}$ \\
\hline HEMLE & $\begin{array}{l}\text { High earnings minus low earnings: monthly return weighted by market value on the portfolio HE, minus monthly return weighted by } \\
\text { the market value on the portfolio LE. }\end{array}$ \\
\hline
\end{tabular}

Then, the stocks are sorted according to $M V, B / M$, and $\mathrm{E} / \mathrm{P}$ and grouped into portfolios. Each stock belongs to three portfolios: one by size, one by $\mathrm{B} / \mathrm{M}$, and one by $\mathrm{E} / \mathrm{P}$, as shown in Table 2.

Table 2

Classification of stocks

\begin{tabular}{l|l|l}
\hline Criteria & Portfolio & Stocks \\
\hline \multirow{2}{*}{ Size } & S & $\begin{array}{l}50 \% \text { stocks with lower MV, i.e. small company } \\
\text { stocks (Small) }\end{array}$ \\
\cline { 2 - 3 } & B & $\begin{array}{l}50 \% \text { stocks with higher MV, i.e. large company } \\
\text { stocks (Big) }\end{array}$ \\
\hline \multirow{2}{*}{ B/M } & H & $30 \%$ stocks with higher B/M (High) \\
\cline { 2 - 3 } & M & $40 \%$ stocks with average B/M (Medium) \\
\cline { 2 - 3 } & L & $30 \%$ stocks with lower B/M (Low) \\
\hline \multirow{2}{*}{ E/P } & HE & $30 \%$ stocks with higher E/P (High Earnings $)$ \\
\cline { 2 - 3 } & ME & $40 \%$ stocks with average E/P (Medium Earnings $)$ \\
\cline { 2 - 3 } & LE & $30 \%$ stocks with lower E/P (Low Earnings) \\
\hline
\end{tabular}

The final portfolios to be used as dependent variables are simultaneously based on the 3 criteria, in June of each year, remaining with constant composition for the next 12 months. As a result, the following $18(2 \times 3 \times 3)$ portfolios are created, as shown in Table 3. In this case, each stock will belong to only one portfolio.

\section{Table 3 \\ Portfolios formed}

\begin{tabular}{|c|c|}
\hline Portfolio & Criteria \\
\hline S_L_LE & Stocks belonging to the $\mathrm{S}, \mathrm{L}$, and LE groups \\
\hline S_L_ME & Stocks belonging to the $S, L$, and ME groups \\
\hline S_L_HE & Stocks belonging to the $\mathrm{S}, \mathrm{L}$, and HE groups \\
\hline S_M_LE & Stocks belonging to the $S, M$, and LE groups \\
\hline S_M_ME & Stocks belonging to the $S, M$, and ME groups \\
\hline S_M_HE & Stocks belonging to the $S, M$, and HE groups \\
\hline S_H_LE & Stocks belonging to the $\mathrm{S}, \mathrm{H}$, and LE groups \\
\hline S_H_ME & Stocks belonging to the $\mathrm{S}, \mathrm{H}$, and ME groups \\
\hline S_H_HE & Stocks belonging to the $\mathrm{S}, \mathrm{H}$, and $\mathrm{HE}$ groups \\
\hline B_L_LE & Stocks belonging to the $\mathrm{B}, \mathrm{L}$, and LE groups \\
\hline B_L_ME & Stocks belonging to the $\mathrm{B}, \mathrm{L}$, and ME groups \\
\hline B_L_HE & Stocks belonging to the $\mathrm{B}, \mathrm{L}$, and $\mathrm{HE}$ groups \\
\hline B_M_LE & Stocks belonging to the $\mathrm{B}, \mathrm{M}$, and LE groups \\
\hline B_M_ME & Stocks belonging to the $\mathrm{B}, \mathrm{M}$, and $\mathrm{ME}$ groups \\
\hline B_M_HE & Stocks belonging to the $\mathrm{B}, \mathrm{M}$, and $\mathrm{HE}$ groups \\
\hline B_H_LE & Stocks belonging to the $\mathrm{B}, \mathrm{H}$, and LE groups \\
\hline B_H_ME & Stocks belonging to the $\mathrm{B}, \mathrm{H}$, and $\mathrm{ME}$ groups \\
\hline B_H_HE & Stocks belonging to the $\mathrm{B}, \mathrm{H}$, and $\mathrm{HE}$ groups \\
\hline
\end{tabular}

\subsection{Returns to be explained}

The returns on each portfolio i are calculated for each month $t, R_{i, t}$, based on the weighted average returns on stock:

$$
R_{i, t}=\sum_{a=1}^{n} \frac{M V_{a, t} \times R_{a, t}}{V M_{i, t}}
$$

Where $M V_{a, t}$ is the market value of equity of company a at the period $t, R_{a, t}$ is the return on the stock a at the period $\mathrm{t}, \mathrm{n}$ is the number of assets belonging to portfolio $i$, and $M V_{i, t}$ is the market value of the portfolio $i$, equal to the sum of the market capitalization of all stocks comprising portfolio i.

\subsection{Specification of models}

To achieve the first objective, i.e. checking whether portfolios formed by $\mathrm{E} / \mathrm{P}$ ratios have returns significantly different from those provided by the CAPM, we used the methodology developed by Jensen (1968), where the regression intercept, Jensen's alpha, is regarded as the abnormal performance of asset $\mathrm{i}$.

$$
R_{i, t}-R F_{t}=a_{i}+b_{i}\left(R M_{t}-R F_{t}\right)+e_{i, t}
$$

Where $R_{i, t}$ is the return on portfolio $i$ for month $t$, $a$ is Jensen's alpha, and $R M_{t}-R F_{t}$ is the return on the market portfolio in excess to the risk-free rate for month $\mathrm{t}$, as defined in Table 1.

For these regressions, we used as dependent variables the monthly returns on extreme portfolios formed by a single criterion (HE and LE). For illustrative purposes, in addition to the returns on portfolios formed based on $\mathrm{E} / \mathrm{P}$ ratios, we also tested returns on extreme portfolios based on size and M/B criteria.

The hypothesis associated with Equation 1 is that portfolios based on $\mathrm{E} / \mathrm{P}$ ratios should have significant intercepts - positive for the high $\mathrm{E} / \mathrm{P}$ portfolio and negative for the low E/P portfolio. This is due to the fact that high (low) E/P stocks tend to have high (low) expected 
returns, such as in the Easton (2004) ex ante model, and we assume that realized returns are a function of expected returns. More formally:

$$
\begin{aligned}
& \mathrm{H} 1_{0}: \mathrm{a}_{\mathrm{i}}=0 \\
& \mathrm{H}{ }_{\mathrm{a} 1}: \mathrm{a}_{\mathrm{i}}>0, \text { when } \mathrm{i}=\mathrm{HE} \\
& \mathrm{H} 1_{\mathrm{a} 2}: \mathrm{a}_{\mathrm{i}}<0, \text { when } \mathrm{i}=\mathrm{LE}
\end{aligned}
$$

To test asset pricing models that include the HEMLE risk factor as an explanatory variable for returns, we used regressions similar to those developed by Fama and French (1993). The models used are the following:

Model 1: $\quad R_{i, t}-R F_{t}=a_{i}+b_{i}\left(R M_{t}-R F_{t}\right)+e_{i, t}$
Model 2:
Model 3: $\quad R_{i, t}-R F_{t}=a_{i}+b_{i}\left(R M_{t}-R F_{t}\right)+k_{i}\left(H E M L E_{t}\right)+e_{i, t}$

For these regressions, we used monthly returns on 18 portfolios formed by the criteria size, $\mathrm{M} / \mathrm{B}$, and $\mathrm{E} / \mathrm{P}$ as dependent variables $\left(\mathrm{R}_{\mathrm{i}, \mathrm{t}}\right)$, as described in Table 1 .

Our central hypothesis is that the $\mathrm{E} / \mathrm{P}$ risk factor, HEMLE, should be relevant to explain returns on the five models [Equations (2) to (6)].
$\mathrm{H} 2: \mathrm{k}_{\mathrm{i}}=0$

$\mathrm{H} 2: \mathrm{k}_{\mathrm{i}} \neq 0$

All regressions used the ordinary least squares (OLS) estimator with the heteroskedasticity-consistent errors, as proposed by White (1980). We assume i.i.d. returns, without correction for serial correlation, as well as exogenous regressors.

\section{RESULTS}

\subsection{Jensen's alphas of portfolios based on a single} risk factor

Table 4 shows that, as expected, the market risk factor coefficient, $\mathrm{b}$, was positive and significantly different from zero for all single-criterion extreme portfolios ( $S$, $\mathrm{B}, \mathrm{H}, \mathrm{L}, \mathrm{HE}, \mathrm{ME}$ ), in line with the results obtained by Fama and French (1993).

The coefficient a (Jensen's alpha) was positive and significant with $\mathrm{p}<1 \%$ for the HE portfolio, i.e. it is clear that companies with high E/P showed consisten- tly higher realized returns than those predicted by the CAPM in Brazil. Such results are qualitatively similar to the findings obtained by Basu (1977) and Costa Jr. and Neves (2000). Accordingly, the LE portfolio had a negative alpha. These results confirm the first hypothesis.

Similar analyses were repeated for portfolios not weighted by the market value of the stocks, i.e. equally weighed. The alpha of portfolio HE remains positive and significant and portfolio LE remains negative and significant, reinforcing the robustness of results.

\begin{tabular}{|c|c|c|c|c|c|c|c|}
\hline \multirow{2}{*}{ Portfolio } & \multicolumn{2}{|c|}{$\mathbf{a}$} & \multicolumn{3}{|c|}{ b } & \multirow{2}{*}{$\mathbf{R}^{2}$} & \multirow{2}{*}{ No. of obs. } \\
\hline & Coef. & $t$ & Coef. & $t$ against 0 & $t$ against 1 & & \\
\hline $\mathrm{S}$ & 0.010 & $(2.975)^{* * *}$ & 0.573 & $(8.339)^{* * *}$ & $(-6.21)^{* * *}$ & 0.422 & 219 \\
\hline B & -0.001 & $(-0.966)$ & 1.000 & $(94.92)^{* * *}$ & $(0.00)$ & 0.988 & 219 \\
\hline $\mathrm{H}$ & -0.002 & $(-0.366)$ & 1.058 & $(12.60)^{* * *}$ & $(0.69)$ & 0.549 & 219 \\
\hline $\mathrm{L}$ & -0.001 & $(-0.840)$ & 0.915 & $(38.44)^{* * *}$ & $(-3.57)^{* * *}$ & 0.898 & 219 \\
\hline $\mathrm{HE}$ & 0.013 & $(3.336)^{* * *}$ & 0.859 & $(13.92)^{* * *}$ & $(-2.28)^{* * *}$ & 0.555 & 219 \\
\hline LE & -0.004 & $(-2.003)^{* *}$ & 0.963 & $(28.77)^{* * *}$ & $(-1.11)$ & 0.853 & 219 \\
\hline
\end{tabular}

Table 4

Estimated Jensen's alphas

*** $p<0.01, * * p<0.05, * p<0.10$.

Table 4 also shows that the coefficient b (CAPM's beta) for the portfolio of large companies (B) is close to 1 and the regressions' $\mathrm{R}^{2}$ is close to $100 \%$. This fact was expec- ted, given that the market portfolio is weighted by the market value of companies, with $96 \%$ of all market capitalization in Brazil deriving from companies in portfolio B. 
In contrast, the portfolio comprising small companies (S) has a lower beta and positive Jensen's alpha. The low beta stems from two facts. First, from the low correlation with the portfolio of large companies (B), whose returns are similar to those of the market portfolio, being necessarily lower than 1 . Second, the standard deviation of portfolio $S$ is also lower than that of $B$, due to the low liquidity of the stocks of small companies, whose prices tend to remain unchanged for a relatively large number of trading days. The alpha of portfolio $S$ is positive and significant, offsetting the effect of the portfolio's low beta.

As a robustness check, the analysis was repeated with the market portfolio returns calculated without weighting by market value, i.e. equally weighed market returns. In this case, the betas of portfolios $\mathrm{S}$ and $\mathrm{B}$ are closer to 1 and the alphas are closer to zero.

Additionally, portfolio L showed a beta significantly lower than 1 , something consistent with most of the literature, which finds that the stocks of companies with lower B/M (growth) have consistently lower returns to high B/M (value) (Fama \& French, 1996, 1998; Yoshino \& Santos, 2009).

\subsection{One-factor models: market}

Similarly to other Brazilian studies, such as Málaga and Securato (2004) and Mussa et al. (2007), just as expected, we identified that the market risk factor was relevant to explain the return on all portfolios, with the coefficient $\mathrm{b}$ being positive and highly significant. The coefficients a (Jensen's alpha) were significant for 5 out of the 18 portfolios, suggesting that the market risk factor, albeit relevant, was not enough to explain the portfolios' realized returns, contradicting the CAPM's predictions. Table 5 shows these results.

Table 5 Estimated parameters for the one-factor model

$$
R_{i, t}-R F_{t}=a_{i}+b_{i}\left(R M_{t}-R F_{t}\right)+e_{i, t}
$$

Monthly returns on portfolios based on stock market capitalization, E/P and B/M ratios, for a sample of Brazilian stocks from January 1995 to March 2013. Value-weighted market portfolio return. Monthly SELIC rate.

\begin{tabular}{|c|c|c|c|c|}
\hline \multirow{2}{*}{ Portfolio } & \multicolumn{2}{|c|}{ Coefficients and t-statistics in parentheses } & \multirow{2}{*}{ Obs. } & \multirow{2}{*}{$\mathbf{R}^{2}$} \\
\hline & a & b & & \\
\hline \multirow[t]{2}{*}{ S_L_LE } & -0.00425 & $0.561^{* * *}$ & 202 & 0.081 \\
\hline & $(-0.426)$ & $(3.917)$ & & \\
\hline \multirow[t]{2}{*}{ S_L_ME } & $-6.13 e-05$ & $0.542^{* * *}$ & 219 & 0.118 \\
\hline & $(-0.00819)$ & $(3.849)$ & & \\
\hline \multirow[t]{2}{*}{ S_L_HE } & 0.0115 & $0.768^{* * *}$ & 183 & 0.157 \\
\hline & $(1.228)$ & $(5.922)$ & & \\
\hline \multirow[t]{2}{*}{ S_M_LE } & -0.00493 & $0.606^{* * *}$ & 214 & 0.133 \\
\hline & $(-0.611)$ & $(3.844)$ & & \\
\hline \multirow[t]{2}{*}{ S_M_ME } & $0.0106^{* *}$ & $0.620^{* * *}$ & 219 & 0.340 \\
\hline & $(2.402)$ & $(10.32)$ & & \\
\hline \multirow[t]{2}{*}{ S_M_HE } & $0.0104^{* *}$ & $0.551^{* * *}$ & 219 & 0.325 \\
\hline & $(2.543)$ & (8.999) & & \\
\hline \multirow[t]{2}{*}{ S_H_LE } & 0.00973 & $0.591^{* * *}$ & 219 & 0.154 \\
\hline & $(1.370)$ & $(4.745)$ & & \\
\hline \multirow[t]{2}{*}{ S_H_ME } & 0.00941 & $0.624^{* * *}$ & 217 & 0.224 \\
\hline & $(1.591)$ & (8.698) & & \\
\hline \multirow[t]{2}{*}{ S_H_HE } & $0.0138^{* *}$ & $0.578^{* * *}$ & 219 & 0.215 \\
\hline & $(2.433)$ & $(4.621)$ & & \\
\hline \multirow[t]{2}{*}{ B_L_LE } & $-0.00495^{* *}$ & $0.870^{* * *}$ & 219 & 0.784 \\
\hline & $(-2.125)$ & (23.99) & & \\
\hline \multirow[t]{2}{*}{ B_L_ME } & 0.00345 & $0.942^{* * *}$ & 219 & 0.782 \\
\hline & $(1.370)$ & $(23.43)$ & & \\
\hline \multirow[t]{2}{*}{ B_L_HE } & 0.00654 & $0.723^{* * *}$ & 166 & 0.310 \\
\hline & (1.010) & (9.019) & & \\
\hline \multirow[t]{2}{*}{ B_M_LE } & $2.23 \mathrm{e}-05$ & $0.916^{* * *}$ & 219 & 0.527 \\
\hline & $(0.00511)$ & (11.45) & & \\
\hline \multirow[t]{2}{*}{ B_M_ME } & -0.000416 & $1.017^{* * *}$ & 219 & 0.739 \\
\hline & $(-0.133)$ & $(22.41)$ & & \\
\hline \multirow[t]{2}{*}{ B_M_HE } & $0.00751^{*}$ & $0.796^{* * *}$ & 219 & 0.471 \\
\hline & (1.754) & $(12.93)$ & & \\
\hline \multirow[t]{2}{*}{ B_H_LE } & -0.00412 & $1.030^{* * *}$ & 219 & 0.354 \\
\hline & $(-0.589)$ & (9.279) & & \\
\hline \multirow[t]{2}{*}{ B_H_ME } & -0.00280 & $0.879 * * *$ & 195 & 0.398 \\
\hline & $(-0.467)$ & (9.728) & & \\
\hline \multirow[t]{2}{*}{ B_H_HE } & 0.00809 & $0.920^{* * *}$ & 205 & 0.243 \\
\hline & $(0.940)$ & (5.693) & & \\
\hline
\end{tabular}

$* * * p<0.01, * * p<0.05, * p<0.10$. 
In order to make the interpretation of Table 5 easier, significance levels of the intercepts of the 18 regressions. Table 6 displays a summary containing only the signs and

Table 6 Significance of the intercepts of portfolios

\begin{tabular}{|c|c|c|c|}
\hline Criteria & LE & ME & HE \\
\hline $\mathbf{H}$ & $\begin{array}{c}\text { no significant } \\
\text { alpha }\end{array}$ & $\begin{array}{c}\text { no significant } \\
\text { alpha }\end{array}$ & $\begin{array}{c}\text { S_H_HE: } \\
\text { positive, } p<0.05\end{array}$ \\
\hline M & $\begin{array}{c}\text { no significant } \\
\text { alpha }\end{array}$ & $\begin{array}{c}\text { S_M_ME: } \\
\text { positive, } p<0.05\end{array}$ & $\begin{array}{c}\text { S_M_HE: } \\
\text { positive, } p<0.05 \\
\text { B_M_HE: } \\
\text { positive, } p<0.10\end{array}$ \\
\hline $\mathbf{L}$ & $\begin{array}{c}\text { B_L_LE: } \\
\text { negative, } p<0.05\end{array}$ & $\begin{array}{c}\text { no significant } \\
\text { alpha }\end{array}$ & $\begin{array}{c}\text { no significant } \\
\text { alpha }\end{array}$ \\
\hline
\end{tabular}

Not surprisingly, the portfolios of stocks that are "cheap" according to the two criteria ( $\mathrm{H}$ by $\mathrm{B} / \mathrm{M}$ and $\mathrm{HE}$ by $\mathrm{E} / \mathrm{P}$ ), which may be classified as value stocks, showed higher returns, while the "expensive" portfolios had lower returns. This effect is made stronger by the companies' size, which tends to generate positive intercepts for portfolios of smaller companies and negative intercepts for larger companies. Specifically, the "cheap stocks" portfolios S_H_HE, S_M_HE, B_M_HE, and S_M_ME showed positive and significant intercepts, with a predominance of portfolios comprising small companies ( $S$ ), whereas the "expensive stocks" portfolio B_L_LE sho- wed a negative and significant intercept.

\subsection{Two-factor models: market and earnings/price}

As shown in Table 7, the HEMLE risk factor was significant to explain returns on most of the portfolios, adding explanatory power to the one-factor model. This is consistent with the expected results of our second hypothesis test. The addition of the HEMLE risk factor also reduced the number of portfolios where the intercept (a) was significant: only 2 out of the 18 portfolios, compared to 5 in the one-factor model. Again, the market factor was highly significant for all portfolios.

\section{Table 7 Estimated parameters for the two-factor model}

$$
R_{i, t}-R F_{t}=a_{i}+b_{i}\left(R M_{t}-R F_{t}\right)+k_{i}\left(H E M L E_{t}\right)+e_{i, t}
$$

Monthly returns on portfolios based on the stock market capitalization, E/P and B/M ratios, for a sample of Brazilian stocks from January 1995 to March 2013. Value-weighted market portfolio return. Monthly SELIC rate. Monthly return on the high E/P portfo-

lio minus the monthly return on the low E/P portfolio.

\begin{tabular}{|c|c|c|c|c|c|}
\hline \multirow{2}{*}{ Portfolio } & \multicolumn{3}{|c|}{ Coefficients and t-statistics in parentheses } & \multirow{2}{*}{ Obs. } & \multirow{2}{*}{$\mathbf{R}^{2}$} \\
\hline & a & b & k & & \\
\hline S_L_LE & $\begin{array}{l}-0.0127 \\
(-1.372)\end{array}$ & $\begin{array}{c}0.579 * * * \\
(4.524)\end{array}$ & $\begin{array}{c}0.492^{* *} \\
(2.208)\end{array}$ & 202 & 0.131 \\
\hline S_L_ME & $\begin{array}{c}-0.00181 \\
(-0.255)\end{array}$ & $\begin{array}{c}0.553 * * * \\
(3.868)\end{array}$ & $\begin{array}{c}0.103 \\
(0.905)\end{array}$ & 219 & 0.122 \\
\hline S_L_HE & $\begin{array}{c}0.00755 \\
(0.782)\end{array}$ & $\begin{array}{c}0.801^{* * *} \\
(6.283)\end{array}$ & $\begin{array}{c}0.298^{* *} \\
(2.105)\end{array}$ & 183 & 0.177 \\
\hline S_M_LE & $\begin{array}{c}-0.00613 \\
(-0.698)\end{array}$ & $\begin{array}{c}0.612^{* * *} \\
(3.898)\end{array}$ & $\begin{array}{l}0.0684 \\
(0.655)\end{array}$ & 214 & 0.134 \\
\hline S_M_ME & $\begin{array}{c}0.0103^{* *} \\
(2.229)\end{array}$ & $\begin{array}{c}0.622^{* * *} \\
(9.938)\end{array}$ & $\begin{array}{l}0.0163 \\
(0.244)\end{array}$ & 219 & 0.340 \\
\hline S_M_HE & $\begin{array}{c}0.00746^{*} \\
(1.794)\end{array}$ & $\begin{array}{c}0.570^{* * *} \\
(9.724)\end{array}$ & $\begin{array}{c}0.176^{* * *} \\
(2.774)\end{array}$ & 219 & 0.353 \\
\hline S_H_LE & $\begin{array}{c}0.00783 \\
(1.041)\end{array}$ & $\begin{array}{c}0.602^{* * *} \\
(4.666)\end{array}$ & $\begin{array}{c}0.112 \\
(0.633)\end{array}$ & 219 & 0.158 \\
\hline S_H_ME & $\begin{array}{c}0.00713 \\
(1.064)\end{array}$ & $\begin{array}{c}0.637^{* * *} \\
(9.267)\end{array}$ & $\begin{array}{c}0.134 \\
(1.159)\end{array}$ & 217 & 0.232 \\
\hline B_L_LE & $\begin{array}{c}-0.00237 \\
(-0.996)\end{array}$ & $\begin{array}{c}0.855^{* * *} \\
(24.24)\end{array}$ & $\begin{array}{c}-0.152^{* * *} \\
(-4.101)\end{array}$ & 219 & 0.804 \\
\hline B_L_ME & $\begin{array}{c}0.00230 \\
(0.883)\end{array}$ & $\begin{array}{c}0.949^{* * *} \\
(24.60)\end{array}$ & $\begin{array}{l}0.0676 \\
(1.576)\end{array}$ & 219 & 0.785 \\
\hline B_L_HE & $\begin{array}{c}-0.00182 \\
(-0.278)\end{array}$ & $\begin{array}{c}0.734^{* * *} \\
(9.647)\end{array}$ & $\begin{array}{c}0.478^{* * *} \\
(3.290)\end{array}$ & 166 & 0.411 \\
\hline B_M_LE & $\begin{array}{c}0.00448 \\
(0.985)\end{array}$ & $\begin{array}{c}0.889 * * * \\
(12.10)\end{array}$ & $\begin{array}{c}-0.263 * * * \\
(-2.727)\end{array}$ & 219 & 0.563 \\
\hline B_M_ME & $\begin{array}{c}-0.00247 \\
(-0.776)\end{array}$ & $\begin{array}{c}1.030^{* * *} \\
(23.41)\end{array}$ & $\begin{array}{c}0.121^{* * *} \\
(2.730)\end{array}$ & 219 & 0.747 \\
\hline B_M_HE & $\begin{array}{c}-0.00158 \\
(-0.452)\end{array}$ & $\begin{array}{c}0.851^{* * *} \\
(15.98)\end{array}$ & $\begin{array}{c}0.536^{* * *} \\
(8.840)\end{array}$ & 219 & 0.648 \\
\hline B_H_LE & $\begin{array}{c}-0.00133 \\
(-0.169)\end{array}$ & $\begin{array}{c}1.013^{* * *} \\
(9.693)\end{array}$ & $\begin{array}{c}-0.165 \\
(-1.383)\end{array}$ & 219 & 0.362 \\
\hline B_H_ME & $\begin{array}{c}-0.00103 \\
(-0.168)\end{array}$ & $\begin{array}{c}0.872^{* * *} \\
(9.726)\end{array}$ & $\begin{array}{l}-0.0888 \\
(-0.966)\end{array}$ & 195 & 0.401 \\
\hline B_H_HE & $\begin{array}{c}-0.00487 \\
(-0.645)\end{array}$ & $\begin{array}{c}1.002^{* * *} \\
(7.032)\end{array}$ & $\begin{array}{c}0.737^{* * *} \\
(4.688)\end{array}$ & 205 & 0.374 \\
\hline
\end{tabular}




\subsection{The Fama and French three-factor model}

The three factors proposed by Fama and French (1993) were relevant to explain the returns on portfolios, although not statistically significant in some of them. Two portfolios had significant Jensen's alphas with $\mathrm{p}<0.05$, suggesting that the three-factor model still lacks explanatory power. These results are similar to those found by other Brazilian studies, including Málaga and Securato (2004), Mussa et al. (2007), and Mussa et al. (2009).

Interestingly, the intercepts were negative and statistically significant for portfolios with low E/P ratios. These results are shown in Table 8.

\section{Table 8 Estimated parameters for the Fama and French three-factor model}

$$
R_{i, t}-R F_{t}=a_{i}+b_{i}\left(R M_{t}-R F_{t}\right)+s_{i}\left(S M B_{t}\right)+h_{i}\left(H M L_{t}\right)+e_{i, t}
$$

Monthly returns on portfolios based on the stocks market capitalization, E/P and B/M ratios, for a sample of Brazilian stocks from January 1995 to March 2013. Value-weighted market portfolio return. Monthly SELIC rate. Monthly return on the small stocks portfolio minus the monthly return on the large stocks portfolio. Monthly return on the high B/M portfolio minus the monthly return on the low B/M portfolio.

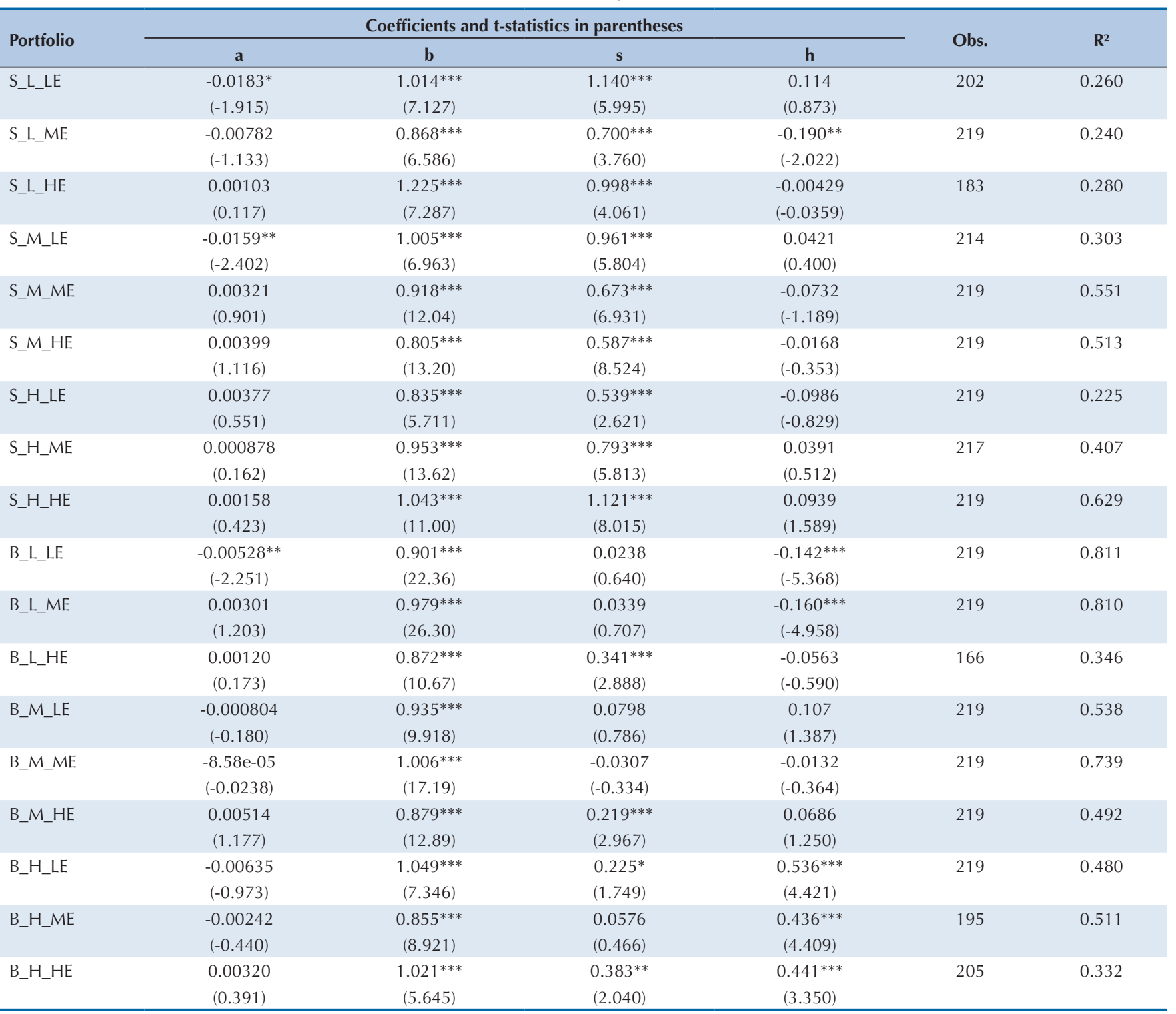

$* * * p<0.01, * * p<0.05, * p<0.10$

\subsection{Three-factor model with market, size and earnings/price}

Table 9 shows that the proposed three-factor model, which replaces HEMLE by HML, proved to be better for the traditional Fama and French three-factor model in the Brazilian market, resulting in only one intercept with $\mathrm{p}<0.05$. The $\mathrm{k}$ coefficient was significant with $\mathrm{p}<0.05$ in 9 out of the 18 regressions, compared to 6 regressions for the h coefficient in the Fama and French three-factor model. 
Table 9 Estimated parameters for the earnings/price three-factor model

$$
R_{i, t}-R F_{t}=a_{i}+b_{i}\left(R M_{t}-R F_{t}\right)+s_{i}\left(S M B_{t}\right)+k_{i}\left(H E M L E_{t}\right)+e_{i, t}
$$

Monthly returns on portfolios based on the stocks market capitalization, E/P and B/M ratios, for a sample of Brazilian stocks from January 1995 to March 2013. Value-weighted market portfolio return. Monthly SELIC rate. Monthly return on the small stocks portfolio minus the monthly return on the large stocks portfolio. Monthly return on the high E/P portfolio minus the monthly return on the low E/P portfolio.

\begin{tabular}{|c|c|c|c|c|c|c|}
\hline \multirow{2}{*}{ Portfolio } & \multicolumn{4}{|c|}{ Coefficients and t-statistics in parentheses } & \multirow{2}{*}{ Obs. } & \multirow{2}{*}{$\mathbf{R}^{2}$} \\
\hline & a & b & s & k & & \\
\hline \multirow[t]{2}{*}{ S_L_LE } & $-0.0209 * *$ & $0.999^{* * *}$ & $1.056^{* * *}$ & 0.218 & 202 & 0.265 \\
\hline & $(-2.342)$ & $(6.692)$ & $(5.556)$ & $(1.030)$ & & \\
\hline \multirow[t]{2}{*}{ S_L_ME } & -0.00652 & $0.856^{* * *}$ & $0.764^{* * *}$ & -0.113 & 219 & 0.225 \\
\hline & $(-0.973)$ & $(6.576)$ & $(4.160)$ & $(-0.885)$ & & \\
\hline \multirow[t]{2}{*}{ S_L_HE } & $9.85 \mathrm{e}-05$ & $1.219^{* * *}$ & $0.960^{* * *}$ & 0.1000 & 183 & 0.282 \\
\hline & $(0.0110)$ & (7.121) & (3.674) & $(0.649)$ & & \\
\hline \multirow[t]{2}{*}{ S_M_LE } & $-0.0131 *$ & $1.031^{* * *}$ & $1.062^{* * *}$ & $-0.229^{* *}$ & 214 & 0.316 \\
\hline & $(-1.782)$ & $(7.513)$ & $(6.411)$ & $(-2.034)$ & & \\
\hline \multirow[t]{2}{*}{ S_M_ME } & 0.00559 & $0.928^{* * *}$ & $0.771^{* * *}$ & $-0.202^{* * *}$ & 219 & 0.571 \\
\hline & (1.533) & (12.91) & (9.316) & $(-3.424)$ & & \\
\hline \multirow[t]{2}{*}{ S_M_HE } & 0.00386 & $0.802^{* * *}$ & $0.583^{* * *}$ & 0.0109 & 219 & 0.513 \\
\hline & (1.088) & $(13.12)$ & $(7.464)$ & $(0.164)$ & & \\
\hline \multirow[t]{2}{*}{ S_H_LE } & 0.00433 & $0.828^{* * *}$ & $0.568^{* * *}$ & -0.0484 & 219 & 0.221 \\
\hline & $(0.602)$ & (5.809) & (3.114) & $(-0.261)$ & & \\
\hline \multirow[t]{2}{*}{ S_H_ME } & 0.00208 & $0.967^{* * *}$ & $0.837^{* * *}$ & -0.0997 & 217 & 0.410 \\
\hline & $(0.349)$ & (13.87) & $(6.431)$ & $(-1.019)$ & & \\
\hline \multirow[t]{2}{*}{ S_H_HE } & -0.000232 & $1.039^{* * *}$ & $1.044^{* * *}$ & $0.154^{*}$ & 219 & 0.633 \\
\hline & $(-0.0622)$ & $(11.60)$ & (8.181) & $(1.708)$ & & \\
\hline \multirow[t]{2}{*}{ B_L_LE } & -0.00310 & $0.902^{* * *}$ & $0.119^{* *}$ & $-0.186^{* * *}$ & 219 & 0.810 \\
\hline & $(-1.282)$ & $(21.63)$ & $(2.449)$ & $(-5.352)$ & & \\
\hline \multirow[t]{2}{*}{ B_L_ME } & 0.00221 & $0.955^{* * *}$ & 0.0143 & 0.0636 & 219 & 0.785 \\
\hline & $(0.817)$ & (22.98) & (0.294) & $(1.417)$ & & \\
\hline \multirow[t]{2}{*}{ B_L_HE } & -0.00365 & $0.806^{* * *}$ & 0.172 & $0.433^{* * *}$ & 166 & 0.419 \\
\hline & $(-0.520)$ & (10.31) & $(1.540)$ & $(2.954)$ & & \\
\hline \multirow[t]{2}{*}{ B_M_LE } & 0.00310 & $0.978^{* * *}$ & $0.225^{* *}$ & $-0.326^{* * *}$ & 219 & 0.577 \\
\hline & $(0.677)$ & (12.84) & $(2.512)$ & $(-3.257)$ & & \\
\hline \multirow[t]{2}{*}{ B_M_ME } & -0.00186 & $0.990^{* * *}$ & -0.0989 & $0.149^{* * *}$ & 219 & 0.750 \\
\hline & $(-0.544)$ & $(17.50)$ & $(-0.991)$ & $(2.723)$ & & \\
\hline \multirow[t]{2}{*}{ B_M_HE } & -0.00134 & $0.836^{* * *}$ & -0.0391 & $0.547^{* * *}$ & 219 & $0.64 \varepsilon$ \\
\hline & $(-0.380)$ & (12.37) & $(-0.489)$ & $(8.751)$ & & \\
\hline \multirow[t]{2}{*}{ B_H_LE } & -0.00324 & $1.136^{* * *}$ & $0.309^{* *}$ & $-0.252^{* *}$ & 219 & 0.376 \\
\hline & $(-0.406)$ & $(9.474)$ & $(2.220)$ & $(-2.116)$ & & \\
\hline \multirow[t]{2}{*}{ B_H_ME } & -0.00150 & $0.905^{* * *}$ & 0.0848 & -0.112 & 195 & 0.403 \\
\hline & $(-0.244)$ & (9.674) & (0.638) & $(-1.173)$ & & \\
\hline \multirow[t]{2}{*}{ B_H_HE } & -0.00496 & $1.007^{* * *}$ & 0.0135 & $0.733^{* * *}$ & 205 & 0.374 \\
\hline & $(-0.652)$ & (5.795) & $(0.0753)$ & $(4.382)$ & & \\
\hline
\end{tabular}

*** $\mathrm{p}<0.01, * * \mathrm{p}<0.05, * \mathrm{p}<0.1$.

\subsection{Four-factor models}

The HEMLE risk factor proved to be significant to explain the returns on portfolios even when used along with the three other risk factors - RM-RF, SMB, and HML, as shown in Table 10. Two out of the eighteen portfolios, however, still showed significant intercepts with $\mathrm{p}<0.10$, something which may be an indication that there are other factors explaining the returns not included in the model.

Nevertheless, the four-factor model has been the most efficient to remove intercepts: only one portfo- lio had a significant Jensen's alpha with $\mathrm{p}<0.05$, when compared to two significant intercepts in the three-factor model.

Such results reinforce the idea that the $\mathrm{E} / \mathrm{P}$ ratio is relevant to explain asset returns and it may be used to design investment strategies. As shown in Table 4, the high $\mathrm{E} / \mathrm{P}$ portfolio outperformed the market by around $1.3 \%$ per month after being controlled by the CAPM's market risk. The importance of $\mathrm{E} / \mathrm{P}$ ratio persists after controlling for three factors: as shown in Table 8, two portfolios comprising low $\mathrm{E} / \mathrm{P}$ stocks had negative intercepts. 
Table 10 Estimated parameters for the four-factor model

$$
R_{i, t}-R F_{t}=a_{i}+b_{i}\left(R M_{t}-R F_{t}\right)+s_{i}\left(S M B_{t}\right)+h_{i}\left(H M L_{t}\right)+k_{i}\left(H E M L E_{t}\right)+e_{i, t}
$$

Monthly returns on portfolios based on the stocks market capitalization, E/P and B/M ratios, for a sample of Brazilian stocks from January 1995 to March 2013. Value-weighted market portfolio return.Monthly SELIC rate. Monthly return on the small stocks portfolio minus the monthly return on the large stocks portfolio. Monthly return on the high B/M portfolio minus the monthly return on the low B/M portfolio. Monthly return on the high E/P portfolio minus the monthly return on the low E/P portfolio.

\begin{tabular}{|c|c|c|c|c|c|c|c|}
\hline \multirow{2}{*}{ Portfolio } & \multicolumn{5}{|c|}{ Coefficients and t-statistics in parentheses } & \multirow{2}{*}{ Obs. } & \multirow{2}{*}{$\mathbf{R}^{2}$} \\
\hline & $\mathbf{a}$ & b & s & $\mathbf{h}$ & k & & \\
\hline \multirow[t]{2}{*}{ S_L_LE } & $-0.0207^{* *}$ & $0.992^{* * *}$ & $1.060^{* * *}$ & 0.0902 & 0.202 & 202 & 0.267 \\
\hline & $(-2.336)$ & $(6.968)$ & $(5.551)$ & $(0.716)$ & $(0.960)$ & & \\
\hline \multirow[t]{2}{*}{ S_L_ME } & -0.00683 & $0.875^{* * *}$ & $0.739 * * *$ & $-0.183^{*}$ & -0.0840 & 219 & 0.242 \\
\hline & $(-1.021)$ & $(6.830)$ & $(3.958)$ & $(-1.970)$ & $(-0.671)$ & & \\
\hline \multirow[t]{2}{*}{ S_L_HE } & $8.56 \mathrm{e}-05$ & $1.220^{* * *}$ & $0.960^{* * *}$ & -0.0144 & 0.103 & 183 & 0.283 \\
\hline & $(0.00956)$ & $(7.147)$ & $(3.667)$ & $(-0.127)$ & $(0.682)$ & & \\
\hline \multirow[t]{2}{*}{ S_M_LE } & $-0.0130^{*}$ & $1.024 * * *$ & $1.071^{* * *}$ & 0.0648 & $-0.239 * *$ & 214 & 0.317 \\
\hline & $(-1.770)$ & (7.413) & $(6.454)$ & $(0.647)$ & $(-2.048)$ & & \\
\hline \multirow[t]{2}{*}{ S_M_ME } & 0.00549 & $0.934^{* * *}$ & $0.763^{* * *}$ & -0.0555 & $-0.193^{* * *}$ & 219 & 0.574 \\
\hline & (1.509) & (13.23) & $(9.143)$ & $(-1.008)$ & $(-3.480)$ & & \\
\hline S_M_HE & (1.078) & (13.25) & (7.489) & $(-0.391)$ & $(0.210)$ & & \\
\hline \multirow[t]{2}{*}{ S_H_LE } & 0.00417 & $0.838^{* * *}$ & $0.555^{* * *}$ & -0.0956 & -0.0332 & 219 & 0.225 \\
\hline & (0.589) & (5.998) & $(2.974)$ & $(-0.859)$ & $(-0.189)$ & & \\
\hline \multirow[t]{2}{*}{ S_H_ME } & 0.00219 & $0.962^{* * *}$ & $0.843^{* * *}$ & 0.0498 & -0.108 & 217 & 0.412 \\
\hline & $(0.363)$ & (13.77) & $(6.332)$ & $(0.629)$ & $(-1.045)$ & & \\
\hline \multirow[t]{2}{*}{ S_H_HE } & $-9.73 e-05$ & $1.031^{* * *}$ & $1.055^{* * *}$ & 0.0810 & 0.141 & 219 & 0.638 \\
\hline & $(-0.0266)$ & (11.63) & (8.328) & (1.390) & (1.599) & & \\
\hline \multirow[t]{2}{*}{ B_L_LE } & -0.00331 & $0.915^{* * *}$ & $0.102 * *$ & $-0.127^{* * *}$ & $-0.166^{* * *}$ & 219 & 0.831 \\
\hline & $(-1.464)$ & $(22.45)$ & $(2.292)$ & $(-4.562)$ & $(-4.829)$ & & \\
\hline \multirow[t]{2}{*}{ B_L_ME } & 0.00193 & $0.972^{* * *}$ & -0.00844 & $-0.168^{* * *}$ & $0.0903^{* *}$ & 219 & 0.816 \\
\hline & $(0.778)$ & (25.95) & $(-0.174)$ & $(-5.637)$ & $(2.245)$ & & \\
\hline \multirow[t]{2}{*}{ B_M_LE } & 0.00333 & $0.964^{* * *}$ & $0.243^{* *}$ & $0.139 * *$ & $-0.349 * * *$ & 219 & 0.592 \\
\hline & $(0.760)$ & (12.53) & $(2.556)$ & $(2.170)$ & $(-3.581)$ & & \\
\hline \multirow[t]{2}{*}{ B_M_ME } & -0.00190 & $0.993^{* * *}$ & -0.103 & -0.0273 & $0.153^{* * *}$ & 219 & 0.751 \\
\hline & $(-0.555)$ & (17.45) & $(-1.028)$ & $(-0.748)$ & $(2.764)$ & & \\
\hline \multirow[t]{2}{*}{ B_M_HE } & -0.00131 & $0.834^{* * *}$ & -0.0366 & 0.0186 & $0.544^{* * *}$ & 219 & 0.649 \\
\hline & $(-0.371)$ & $(12.32)$ & $(-0.463)$ & $(0.480)$ & (8.879) & & \\
\hline \multirow[t]{2}{*}{ B_H_LE } & -0.00229 & $1.078^{* * *}$ & $0.386^{* * *}$ & $0.567^{* * *}$ & $-0.342^{* * *}$ & 219 & 0.508 \\
\hline & $(-0.333)$ & (7.786) & (3.291) & (5.281) & $(-3.024)$ & & \\
\hline \multirow[t]{2}{*}{ B_H_ME } & 0.00104 & $0.877^{* * *}$ & 0.163 & $0.471^{* * *}$ & $-0.228^{* *}$ & 195 & 0.529 \\
\hline & $(0.186)$ & (10.12) & (1.492) & (5.037) & $(-2.121)$ & & \\
\hline \multirow[t]{2}{*}{ B_H_HE } & -0.00481 & $0.967^{* * *}$ & 0.0668 & $0.378^{* * *}$ & $0.672^{* * *}$ & 205 & 0.426 \\
\hline & $(-0.654)$ & (6.009) & $(0.391)$ & (3.992) & $(4.793)$ & & \\
\hline
\end{tabular}

*** $\mathrm{p}<0.01, * * \mathrm{p}<0.05, * \mathrm{p}<0.10$.

\subsection{Analysis on the significance of intercepts}

In a seminal paper, Fama and French (1993) show that their three-factor model does a good job to explain the cross-section of average stock returns, because it generates intercepts not significantly different from zero.

In our Brazilian sample, the models using the risk factor HEMLE were the most efficient to eliminate intercepts. All three models including such risk factor re- sulted in only one significant intercept with $\mathrm{p}<5 \%$ each, compared to two in the Fama and French three-factor model and four in the one factor model (CAPM).

The results indicate that any of the models including the HEMLE risk factor, also the two-factor model, are more efficient than the Fama and French three-factor model to explain returns on the Brazilian market, as shown in Table 11. 
Table 11 Analysis on the significance of intercepts

Number of significant intercepts. Each model was applied to the 18 portfolios.

\begin{tabular}{|c|c|c|c|c|c|}
\hline \multirow[b]{2}{*}{$\begin{array}{l}\text { Intercepts' } \\
\text { significance }\end{array}$} & \multirow[b]{2}{*}{$\begin{array}{c}\text { CAPM } \\
\text { (RM-RF) }\end{array}$} & \multirow[b]{2}{*}{$\begin{array}{c}\text { Fama \& French } \\
\text { three-factor model } \\
\text { (RM-RF, SMB, HML) }\end{array}$} & \multicolumn{3}{|c|}{ Models with HEMLE } \\
\hline & & & $\begin{array}{c}\text { Two factors } \\
\text { (RM-RF, HEMLE) }\end{array}$ & $\begin{array}{c}\text { Three factors } \\
\text { (RM-RF, SMB, HEMLE) }\end{array}$ & $\begin{array}{c}\text { Four factors } \\
\text { (RM-RF, SMB, HML, } \\
\text { HEMLE) }\end{array}$ \\
\hline$p<1 \%$ & 0 & 0 & 0 & 0 & 0 \\
\hline $1 \% \leq p<5 \%$ & 4 & 2 & 1 & 1 & 1 \\
\hline$p \geq 5 \%$ & 14 & 16 & 17 & 17 & 17 \\
\hline
\end{tabular}

\section{CONCLUSION}

This study tested the realized returns on portfolios based on the E/P ratio of stocks traded in Brazil, as well as the HEMLE risk factor in asset pricing models. The HEMLE risk factor may be understood as an expected risk/return premium for stocks with high $\mathrm{E} / \mathrm{P}$ ratio, or earnings yield, which can be a good estimate for the company's ex ante or implied cost of capital, in line with the models proposed by Gebhardt et al. (2001), Claus and Thomas (2001), Easton (2004), and Ohlson and Juettner-Nauroth (2005).

Therefore, the results obtained by this study may be understood as a convergence of two major lines of research on cost of equity and asset pricing: designing ex post multi-factor models with a greater number of risk factors and adopting ex ante models. The results show that assets with high implied cost of equity, measured by high E/P ratios, also had better realized returns, as well as that the risk factor related to the high implied cost of equity, HEMLE, is significant to explain returns on stock in Brazil.

We also conclude that, in Brazil, the $\mathrm{E} / \mathrm{P}$ ratio may be more effective to identify "cheap" or "value" stocks, when compared to $\mathrm{B} / \mathrm{M}$ ratios. While portfolios based on $\mathrm{E} / \mathrm{P}$ ratios had abnormal risk-adjusted returns, portfolios formed by $\mathrm{M} / \mathrm{B}$ ratios did not have significant intercepts. Such results are different from those obtained by Fama and French (1995) and Fama and French (1996), who show that the three-factor model may explain the returns on portfolios based on $\mathrm{E} / \mathrm{P}$ ratios. This may be due to the high inflation rate in Brazil, which makes the book values of companies less meaningful, especially for firms with older assets.

More generally, the results also show that using E/P ratios in Brazil to select value stocks resulted in significantly better risk-adjusted performance for investors, even when controlled by the market risk factor. While the market portfolio generated an average monthly ex- cess return over the risk-free rate of $0.6 \%$, the portfolio comprising high $\mathrm{E} / \mathrm{P}$ stocks had a monthly excess return of $1.8 \%$, with a slightly lower beta, resulting in an excess risk-adjusted monthly return close to $1.3 \%$, as shown in Table 4.

More formally, this study confirms the hypotheses that (i) the stocks with high (low) E/P ratios, i.e. potentially high (low) implied a cost of equity, had abnormally high (low) realized returns not captured by the CAPM, and (ii) the HEMLE risk factor was significant to explain stock returns, both in models controlled by the market risk factor and in models jointly controlled by the factors market risk, size risk premium (SMB), and the risk premium related to the $\mathrm{B} / \mathrm{M}$ ratio (HML).

We also conclude that the models using the HEMLE risk factor resulted in a greater ability to eliminate the intercepts of regressions. The two-factor model (market and HEMLE), the three-factor model (market, SMB, and HEMLE), and the four-factor model (market, SMB, HML, and HEMLE) showed less significant intercepts when compared to the Fama and French three-factor model.

A limitation of this study is that the sample, despite being the largest in number of assets and in time period used in Brazil, as far as the authors are aware, is still rather limited when compared to those used by international studies.

These results may encourage further studies assessing the explanatory power of the HEMLE risk factor in other markets, especially those with higher inflation or lower development when compared to the U.S. market, where the most relevant models have been designed. Another possible extension is checking whether E/P ratios constitute better explanatory factors for returns in other countries with historically high inflation rates and whether B/M ratios are more suited for countries with historically low inflation rates. 


\section{References}

Attig, N., Guedhami, O., \& Mishra, D. (2008). Multiple large shareholders, control contests, and implied cost of equity. Journal of Corporate Finance, 14(5), 721-737.

Basu, S. (1977). Investment performance of common stocks in relation to their price-earnings ratios: atest of the efficient market hypothesis. The Journal of Finance, 32(3), 663-682.

Carhart, M. M. (1997). On persistence in mutual fund performance. The Journal of Finance, 52(1), 57-82.

Claus, J., \& Thomas, J. (2001). Equity premia as low as three percent? Evidence from analysts' earnings forecasts for domestic and international stock markets. The Journal of Finance, 56(5), 1629-1665.

Cochrane, J. H. (2010). Presidential address: discount rates. The Journal of Finance, 66(4), 1047-1108

Costa Jr., N., \& Neves, M. (2000). Variáveis fundamentalistas e os retornos das ações. Revista Brasileira de Economia, 1, 123-137.

Easton, P. D. (2004). PE ratios, PEG ratios, and estimating the implied expected rate of return on equity capital. The Accounting Review, 79(1), 73-95.

Fama, E. F., \& French, K. R. (1992). The cross-section of expected stock returns. The Journal of Finance, 47(2), 427-465.

Fama, E. F., \& French, K. R. (1993). Common risk factors in the returns on stocks and bonds. Journal of Financial Economics, 33, 3-56.

Fama, E. F., \& French, K. R. (1995). Size and book-to-market factors in earnings and returns. The Journal of Finance, 50(1), 131-155.

Fama, E. F., \& French, K. R. (1996). Multifactor explanations of asset pricing anomalies. The Journal of Finance, 51(1), 55-84.

Fama, E. F., \& French, K. R. (1998). Value versus growth: the international evidence. The Journal of Finance, 53(6), 1975-1999.

Fama, E. F., \& French, K. R. (2002). The equity premium. The Journal of Finance, 57(2), 637-659.

Fama, E. F., \& French, K. R. (2012). Size, value, and momentum in international stock returns. Journal of Financial Economics, 105(3), $457-472$

Fama, E. F., \& MacBeth, J. D. (1973). Risk, return and equilibrium: empirical tests. The Journal of Political Economy, 81(3), 607-636.

Feltham, G. A., \& Ohlson, J. A. (1995).Valuation and clean surplus accounting for operating and financial activities. Contemporary Accounting Research, 11(2), 689-731.
Gebhardt, W. R., Lee, C. M. C., \& Swaminathan, B. (2001). Toward an implied cost of capital: Journal of Accounting Research, 39(1), 135-176.

Hail, L., \& Leuz, C. (2009). Cost of capital effects and changes in growth expectations around US cross-listings. Journal of Financial Economics, 93(3), 428-454.

Jensen, M: (1968): The performance of mutual funds in the period 19451964. The Journal of Finance, 23(2), 389-416.

Lintner, J. (1965). Security prices, risks and maximal gains from diversification. The Journal of Finance, 20(4), 587-615.

Málaga, F. K., \& Securato, J. R. (2004). Aplicação do modelo de três fatores de Fama e French no mercado acionário brasileiro: um estudo empírico no período 1995-2003. In Encontro Anual da Associação Nacional dos Programas de Pós-Graduação em Administração, 28. Curitiba: Anpad.

Markowitz, H. (1952). Portfolio selection. The Journal of Finance, 7(1), 77-91

Mussa, A., Rogers, P., \& Securato, J. R. (2009). Modelos de retornos esperados no mercado brasileiro: testes empíricos utilizando metodologia preditiva. Revista de Ciências da Adiministração, 11(23), 192-216.

Mussa, A., Santos, J. O., \& Famá, R. (2007). A adição do fator de risco momento ao modelo de precificação de ativos dos três fatores de Fama \& French, aplicado ao mercado acionário brasileiro. In Congresso USP de Controladoria e Contabilidade, 7. São Paulo: USP.

Ohlson, J. A., \& Juettner-Nauroth, B. E. (2000). Expected EPS and EPS growth as determinants of value. Review of Accounting Studies, 10 (23), 349-365

Ohlson, J. A., \& Juettner-Nauroth, B. E. (2005). Expected EPS and EPS growth as determinants of value. Review of Accounting Studies, 10 349-365.

Sharpe, W. F. (1964). Capital asset prices: atheory of market equilibrium under conditions of.risk. The Journal of Finance, 19(3), 425-442.

White, H. (1980). A heteroskedasticity-consistent covariance matrix estimator and a direct test for heteroskedasticity. Econometrica, 48(4), 817-838.

Yoshino, J., \& Santos, E. E. (2009). Is the CAPM dead or alive in the Brazilian market? Review of Applied Economics, 5(1-2), 127-142. 